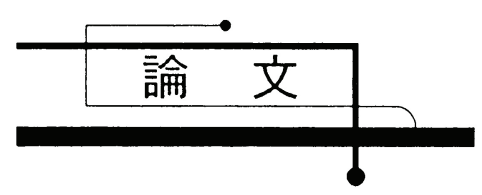

\title{
水平気液二相チャネル乱流における人エボイド波の伝ぱ*
}

\section{Artificial Void Wave Propagation in a Gas-Liquid Two-Phase Horizontal Turbulent Channel Flow}

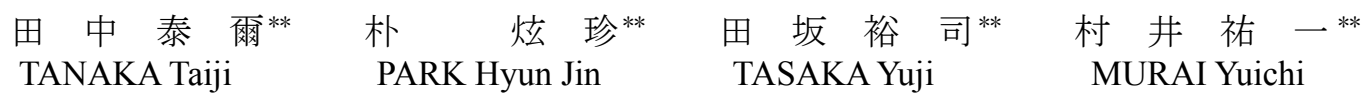

\begin{abstract}
This study aims to reveal the development process of artificial void waves generated in a fully developed turbulent channel flow. Void waves generated with periodically fluctuated air flow rate were optically visualized by a high-speed video camera at three locations along the channel. The measured spatio-temporal fluctuations of void waves maintained the initial frequency given at the injection during the downstream propagation. The diffusion coefficients of void distributions were calculated to evaluate the influence of diffusion in a two-phase turbulent flow. The coefficients denoted that diffusion effect was larger than that of turbulent eddy viscosity on void wave deformation.
\end{abstract}

Keywords: Void wave, Bubble swarm, Turbulent channel flow, Diffusion coefficient

\section{1. 緒 言}

気泡を乱流境界層に注入することにより、壁面 摩擦抵抗の低減が可能になる。BDR (Bubbly Drag Reduction）と呼ばれるこの技術の研究は、 McCormick and Bhattacharyya [1]の電気分解気泡 を用いた実験に端を発する。BDR は、気泡を用 いるため環境を污染しないという特徽をもち、燃 料消費量の削減を目的として、既に実際の船舶で 利用されている。その効果を検証した実船による 実験では、船底に働く摩擦抵抗が $12 \%$ 削減された [2]。この実験では、船底へ空気を注入するための コンプレッサにより $7 \%$ の燃料が消費されたため、 正味の省エネルギー化は 5\%であった。気泡注入 に必要な燃料を低減するため、コンプレッサの代 わりに翼型の気泡注入装置を用いた実船実験に おいては、正味 $10 \%$ の燃料消費量削減が確認され た[3]。

BDR による抵抗低減効果は、一般にボイド率 が高いほど向上するが[4]、気泡径により壁面摩擦 の低減に至る機構が異なるため、気泡径にも左右 される[5]。平板の壁面を覆う大きな気膜を用いた
実験では、乱流境界層全体が壁面から分離される ことにより、数十\%の抵抗低減が確認されている $[6,7]$ 。乱流境界層内の秩序構造よりも十分に小さ な径を持つマイクロバブルは、流れの秩序構造を 変調させることで[8]、低ボイド率でも数\%から数 十\%の高い抵抗低減効果を生じる $[9,10]$ 。巨大な 気膜とマイクロバブルの中間的な大きさの気泡 は、移動する方向の前方側や後方側に渦を生成す ることが、水平チャネル乱流中の気泡近傍の流れ を可視化した実験で確認されている[11]。この渦 が乱流境界層中のせん断応力分布を変化させる ことで、気泡近傍において局所的に壁面摩擦抵抗 が低減される[12]。

中間サイズの気泡は、気泡の合体と分裂がつり 合う条件で発生する。これを乱流境界層に連続的 に注入する場合、境界層内では気泡と乱流の間だ けでなく、気泡と気泡の間にも相互作用が生じ、 壁面の摩擦抵抗低減に至る。このとき、抵抗低減 に寄与する主体は、単一の気泡よりもむしろ、境 界層内に存在する多数の気泡の集合体である。乱 流境界層に注入された気泡の分布は、非常に複雑

* Received: 5 March 2019 / Accepted: 11 November 2019 / Published online: 20 December 2019

** 北海道大学工学院 $\bar{T} 060-8628$ 北海道札幌市北区北 13 条西 8 丁目

TEL: (011)706-6373 FAX: (011)706-6373 E-mail: t.tanaka@ring-me.eng.hokudai.ac.jp 
かつ非定常となる。最新の研究では、親水性や撥 水性などの壁面性状によって気泡のサイズとそ れに依存した空間分布特性が変化することも報 告されている[13]。当グループでは、移動する気 泡の分布に応じて生じる、局所ボイド率の時空間 変動に着目してきた。水平チャネルを用いた実験 においては、ボイド率の周期的変動により抵抗低 減が促進されることが判明している[14]。また、 平板底面のモデル船を用いた実験では、注入時に 一定の空気流量を与えられた多数の気泡が、摩擦 抵抗低減に寄与する過程で自然に粗密分布を形 成し、ボイド率の時空間変動、すなわちボイド波 が発達することが明らかとなった $[15,16]$ 。この 実験結果については、ボイド率変動を一種の波動 として取り扱うことにより、抵抗低減を生じる中 でボイド波が発達することも理論的に証明され ている[15]。

以上の知見からボイド波が生み出す抵抗低減 効果に注目し、人工的に生成したボイド波を用い ることが試みられた。水平チャネル乱流に対して、 間欠的に気泡を注入することで人工ボイド波を 生成した実験では、同じ平均ボイド率においてボ イド率変動を注入時に与えない場合よりも高い 抵抗低減効果が確認された[17]。同様の間欠的な 気泡注入で生成された水平チャネル乱流内の気 泡群が、乱流境界層内の渦構造を一時的に壁面か ら引きはがす様子が、フレーク状粒子を用いて可 視化されている[18]。一定の空気流量で気泡を注 入した場合にボイド波が自然発達したように、人 工ボイド波も移流に伴い変形すると予想される ため、下流におけるボイド波形は明らかでない。 実船舶への技術の適用を考える際は、船底全体で
得る合計の抵抗低減量が問われる。高い抵抗低減 効果を生み出すボイド波の長距離維持のため、ボ イド波の移流中の変形に関する知見が必要とな る。本研究では、チャネル乱流に人工ボイド波を 与え、ボイド波の移流中における発達過程を調査 した。水平チャネル乱流内の人工ボイド波を複数 の流下距離において計測し、ボイド波の下流持続 性と波形の変化を評価した。また、計測されたボ イド波を 1 次元移流拡散方程式に当てはめ、波形 の変化を拡散係数として評価した。

\section{2. 実験装置および実験条件}

\section{1 実験装置}

実験装置の概略図を Fig. 1 に示す。透明アクリ ル製の水平チャネル試験流路の寸法は、全長 $6 \mathrm{~m}$ 、 高さ $40 \mathrm{~mm}$ 、幅 $160 \mathrm{~mm}$ である。流路入口からの 距離を $x$ 軸、チャネル上壁面からの距離を $y$ 軸、 チャネル側面からの距離を $z$ 軸と定義する。流路 内の作動流体として水道水を使用し、ポンプを用 いて水を回流させる。回流寸る水の流量 $\left(Q_{1}\right)$ は、 配管の途中に設置した流量計で測定した。 $x=0.8$ $\mathrm{m}$ の位置のチャネル上壁面に、流れ方向に長さ 2 $\mathrm{mm}$ 、スパン方向に $150 \mathrm{~mm}$ の単スリット形状の 空孔を持つ気泡注入器を設置した。ここにコンプ レッサから空気を供給することにより、チャネル 流路内に気泡が注入される。気泡注入のための空 気流量は、東京ガス株式会社が開発したガス流量 制御装置[19]を小型に設計し直して制御した。流 路に注入された気泡は、チャネル後端に設置した タンク内で取り除かれる。このため、ポンプを用 いて作動流体を回流させる際に、気泡が再び試験 流路に戻ることはない。

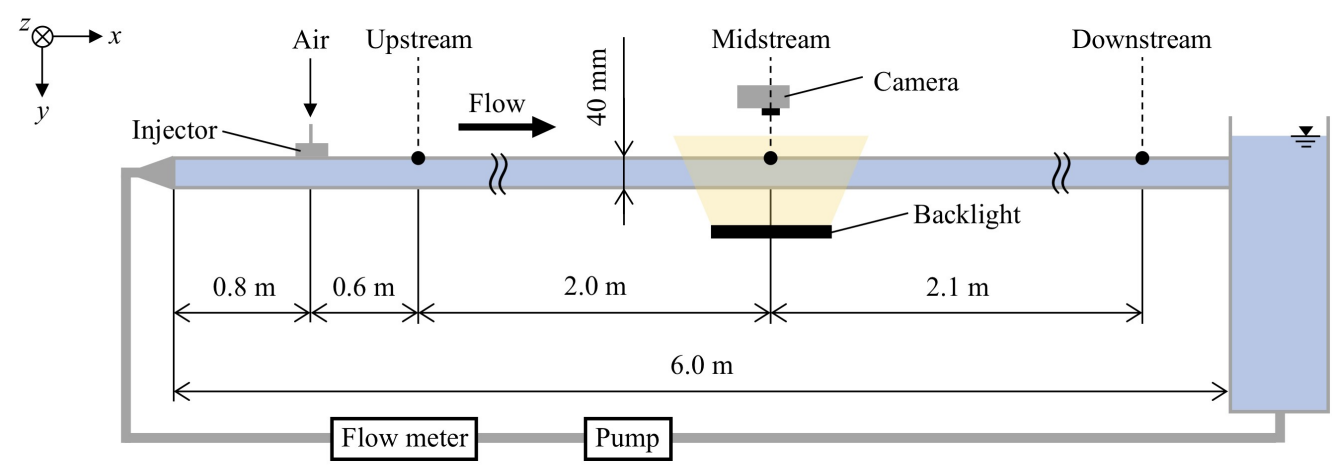

Fig. 1 Schematic diagram of experimental setup. 
Table 1 Parameters of the high-speed video camera.

\begin{tabular}{ll}
\hline Frame size & $1280 \times 1024$ pixel \\
Resolution & $0.145 \mathrm{~mm} /$ pixel \\
Recording time & $6.0 \mathrm{~s}$ \\
Frame rate & $500 \mathrm{fps}$ \\
\hline
\end{tabular}

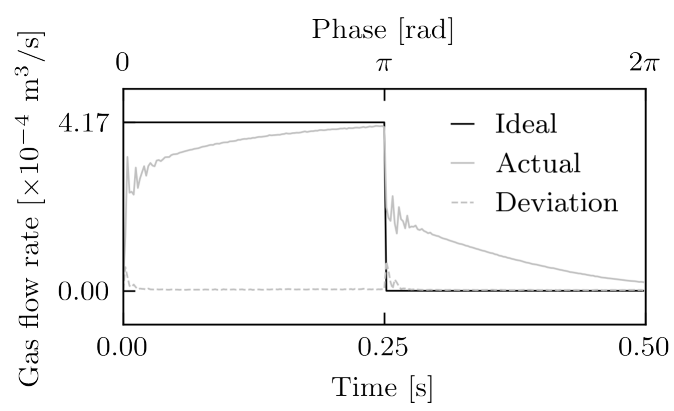

Fig. 2 Phase diagram of gas flow rate at the injection point.

流路内を移動する気泡は、チャネルの下側に設 置した白色バックライト照明を光源として、チャ ネルの上側に設置した高速度カメラ（CR600×2， Optronis $\mathrm{GmbH}$ ) により撮影した。計測における カメラの設定を Table 1 に示す。バックライト照 明の輝度は、撮影された画像において気液界面に 生じる影が明瞭になるように調整した。

\section{2 実験条件}

チャネル乱流内に人工ボイド波を生成するた め、空気流量は注入周波数 $f=2 \mathrm{~Hz}$ の、間欠的 な矩形波に制御した (Fig. 2 の黒実線)。流量制 御装置の性能限界と、気泡注入部の空孔付近にお ける圧力バランス変動により、空気流量波形は理 想的な形状にはならない。Fig. 2 に、実際に流路 に注入された空気流量の波形を 1 周期間隔でア ンサンブル平均した結果を、灰色の実線で示す。 平均の波形は矩形とならず、最小の流量がゼロと ならなかった。しかし、矩形波の立ち上がりと立 ち下がりに対応して急激に空気流量が変化する 位相で、灰色の破線で示したアンサンブル平均の 標準偏差が十分に小さい值である。このため、実 際の空気流量波形について再現性は保たれた。

チャネル流路断面の平均流速は、

$$
u_{\mathrm{m}}=\frac{Q_{\mathrm{l}}}{2 H \times W}
$$

と定義される。ここで、 $H$ および $W$ はチャネル 流路の半高さと幅を表す。チャネル乱流の流速が (a)

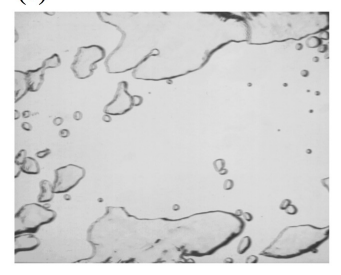

(b)

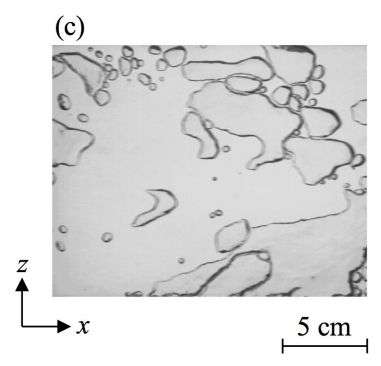

Fig. 3 Snapshots of bubbles in a horizontal turbulent channel flow at (a) upstream, (b) midstream and (c) downstream measurement regions. (a)

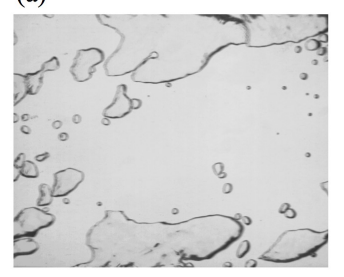

(b)

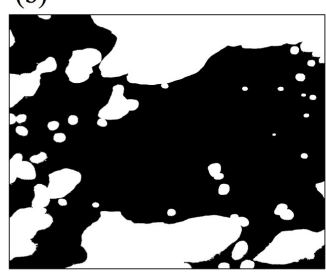

Fig. 4 An example of image processing, (a) original image and (b) binarized image: white area represents air phase in (b).

小さく、注入する空気流量が大きい場合、移動中 に気泡の結合が進み、撮影された画像において気 相と液相の判別を困難にする大気泡が生成され る。これを避けるため、 $u \mathrm{~m}$ は $1.40 \mathrm{~m} / \mathrm{s}$ 、空気流量 の最大值は $4.17 \times 10^{-4} \mathrm{~m}^{3} / \mathrm{s}$ に設定した。水の動粘 性係数（v）を用いてチャネルを流れる水流のレ イノルズ数を

$$
R e=\frac{u_{\mathrm{m}} H}{v}
$$

と定義する。また、平均空気流量を $Q_{\mathrm{g}}$ とすると、 流路内の平均ボイド率は

$$
\alpha_{\mathrm{m}}=\frac{Q_{\mathrm{g}}}{Q_{1}+Q_{\mathrm{g}}}
$$


(a)
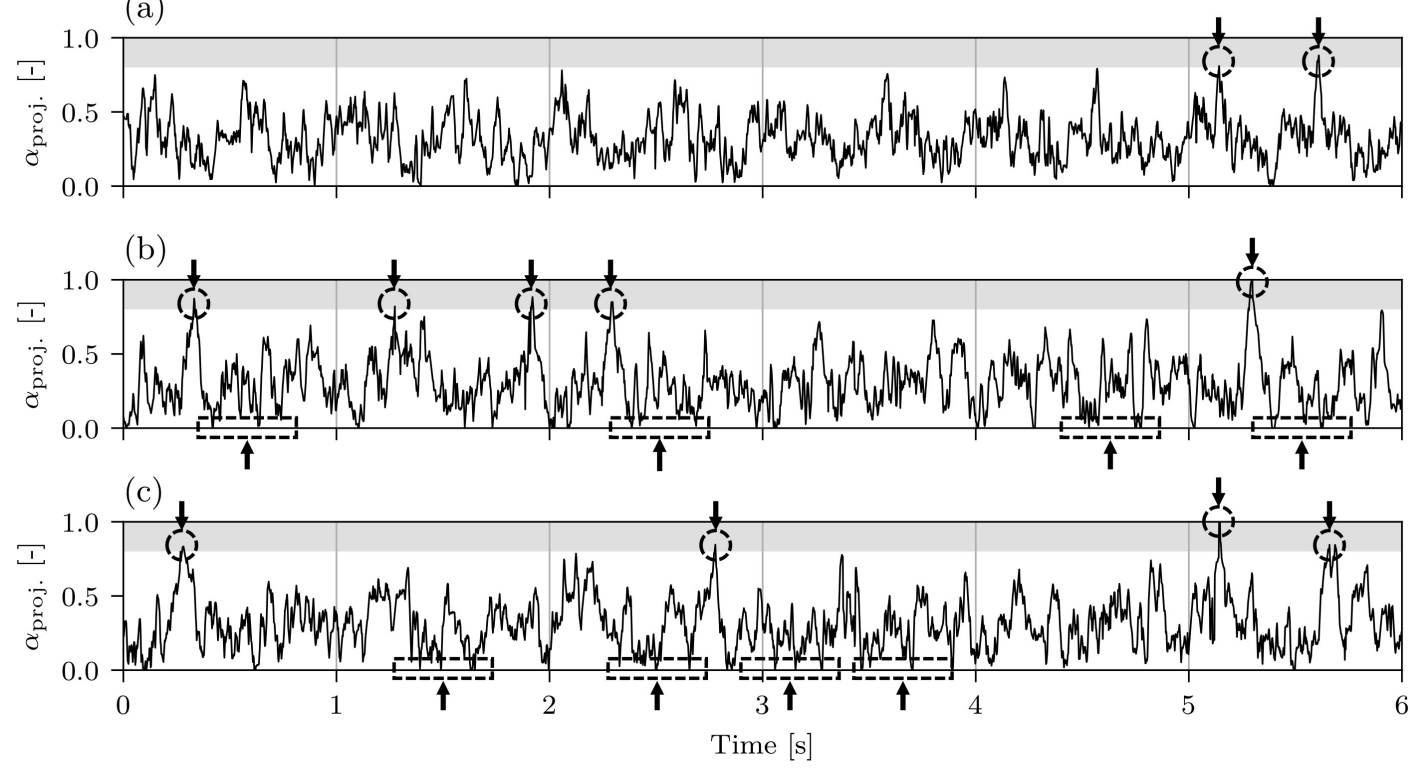

Fig. 5 Waveforms of projection void fraction measured at (a) upstream, (b) midstream and (c) downstream measurement regions: dashed circles highlight high projection void fraction and dashed squares highlight zero projection void fraction appearing several times in short time.

と求められる。実験において、 $R e=2.75 \times 10^{4} 、 \alpha_{\mathrm{m}}$

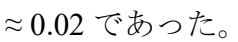

移動する気泡は、気泡注入直後であるチャネル 上流 $(x=1.4 \mathrm{~m})$ 、チャネル中流 $(x=3.4 \mathrm{~m})$ 、流 路後端直前のチャネル下流 $(x=5.5 \mathrm{~m})$ の 3 点で、 6 秒間ずつ撮影した。各位置での撮影は独立して 行われたため、それぞれの撮影で別の気泡が記録 されている。

\section{3. 結果と考察}

\section{1 ボイド波の周期的特徵}

Fig. 3 に示すように、高速度カメラで撮影され た画像では、気泡と液相の界面で光源から照射さ れた光が屈折することにより、気泡の輪郭が黒い 影として映る。撮影された画像から、等価面積を 考えた気泡半径 $(r)$ が $1 \mathrm{~mm}<r<100 \mathrm{~mm}$ 程度で あることが確認できる。この画像に対して、気泡 の輪郭を検出した後、輪郭が構成する閉曲線の内 部を気相と判定する画像処理を施すことにより、 気相と液相が区別された二值化画像を得た。例と して、この画像処理を Fig. 3(a)に行った結果を Fig. 4 に示す。この画像処理手法は、気泡が孤立
して存在するとき、精度よく気相と液相を区別で きる。一方、気泡が密集しているとき、気泡近傍 の液相が誤って気相として判定される場合があ る。

二值化画像において、気相部分に当たる白色の ピクセルが $z$ 方向に占める割合を、投影ボイド率 （ $\alpha_{\text {proj. }} ）$ と定義する。本報では、この投影ボイド 率の時空間変動をボイド波として議論する。画像 処理における誤判定により、投影ボイド率の瞬時 值には過大評価が生じうる。しかし、極端なボイ ド率変動を人工的に与えた本報において、この過 大評価は投影ボイド率の周期的な変動の議論に 大きく影響しない。

\subsection{1 ボイド波の周期性}

撮影された動画について、 $x$ 方向中央の 1 ピク セル幅の領域における、投影ボイド率の時間変化 を Fig. 5 に示す。Fig. 5 に破線の丸で示す通り、 中流および下流で計測された波形では、上流より も高い頻度でボイド率が瞬間的に高くなる。また、 中流と下流では、短時間に繰り返しボイド率がゼ ロとなる波形が現れている。このようにボイド率 の増減の幅が中流・下流で大きくなったのは、移 
(a)

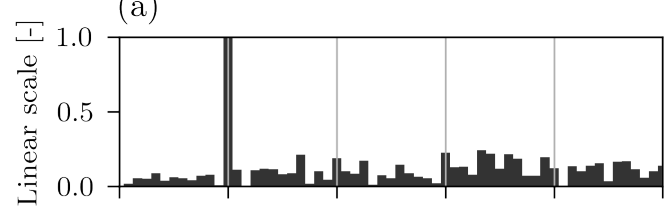

(b)

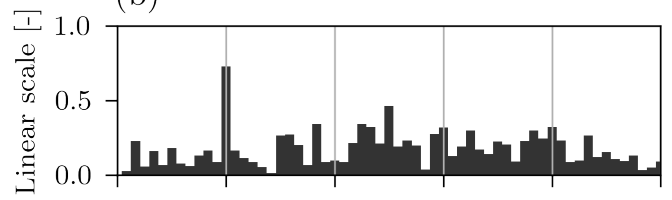

(c)

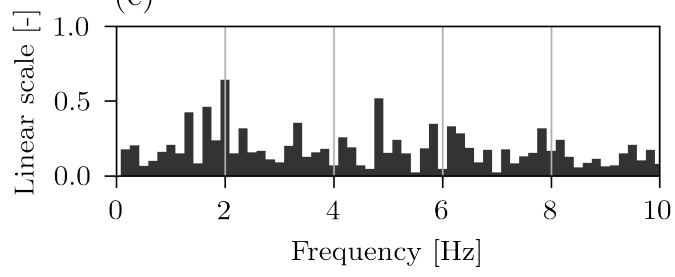

Fig. 6 Linear spectra of artificial void waves at (a) upstream, (b) midstream and (c) downstream measurement regions: the spectra are normalized by the value of the largest component in (a).

動中に気泡同士の結合が生じ、大気泡の部分と小 気泡を含む液体部分が存在するスラグ流状の流 動様式へと変化したことを示す。

ボイド率の増減の幅は上流より中流・下流で大 きくなった一方、ボイド率変動の周期性は上流と 比較して中流・下流でやや不明瞭となって見える。 Fig. 5 のボイド波に対してフーリエ変換を施して 得られたスペクトルを Fig. 6 に示す。いずれのス ペクトルにおいても、 $2 \mathrm{~Hz}$ に最大のピークが現れ た。注入時の空気流量は $2 \mathrm{~Hz}$ の矩形波となるよ う制御したため、人工的に与えた周期性が下流に おいても維持されたことが確認できる。しかしな がら、中流において、 $2 \mathrm{~Hz}$ の成分が上流よりも弱 まると同時に、それ以外の周波数成分が発達した。 下流ではこの傾向がさらに進行し、 $2 \mathrm{~Hz}$ の成分と 同程度の大きさの成分が $5 \mathrm{~Hz}$ 付近に現れた。こ れは、移流中にボイド波が変形したことを示して いる。一定流量で流れに気泡を注入した場合に気 液二相乱流内でボイド波が自然に発達すること が報告されており、この効果が間欠的に気泡を注 入した本実験でも現れたと考えられる。

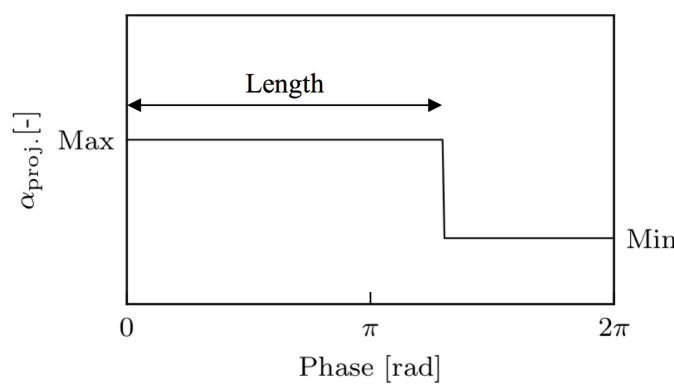

Fig. 7 Definition of approximate rectangular wave.

\section{1 .2 位相平均波の特徵}

1 周期の気泡注入で生成されたワンショット分 の気泡の集まりを、気泡群と呼ぶこととする。以 降では、気泡群に対応する 1 周期分のボイド率変 動に着目する。フーリエ変換によって確認された $2 \mathrm{~Hz}$ の周期性に基づき、 1 周期すなわち 0.5 秒ご との波形から位相平均波を計算した。ここで、位 相平均波の主な特徵を、注入時の空気流量に与え た矩形の波形に対応づけて評価するため、Fig. 7 に示寸近似矩形波を導入する。近似矩形波は、注 入時の空気流量波形と同様に $2 \mathrm{~Hz}$ の周期性を持 ち、(1)立ち上がりの位相の位置、(2)最大值、(3) 最小值、(4)最大值が継続する時間の長さにより定 義される。この 4 要素を独立に変化させ、位相平 均波と近似矩形波が最もよく合致する条件を、各 位相における差の平方について位相方向で総和 をとる最小二乗法により求め、近似矩形波を決定 した。

Fig. 8 に、近似矩形波の立ち上がりの位相がゼ 口となるように調整した位相平均波および近似 矩形波を示す。位相平均は 12 周期分の波形を用 いて行われており、元の波形の細かな変動を消失 させるほどの標本数ではない。このため、位相平 均波にも細かな変動が残っている。この波形は、 計測を繰り返すことで周期波形の標本数を増や すと、より滑らかな形状に近づく。Fig. 9 は位相 平均波を求める際に計算した、位相ごとの標準偏 差である。標準偏差の值は平均の值と比較して小 さく、 1 周期ごとの波形に再現性が確認される。 位相平均波の主な特徵を示寸近似矩形波につ いて、最小值が上流から下流にかけて約 $23 \%$ 増大 した。本実験でチャネル乱流に注入された気泡径 の範囲においては、大きい径の気泡の移動速度が、 小さい径の気泡と比べて 1.5 倍前後になる [18]。 
(a)

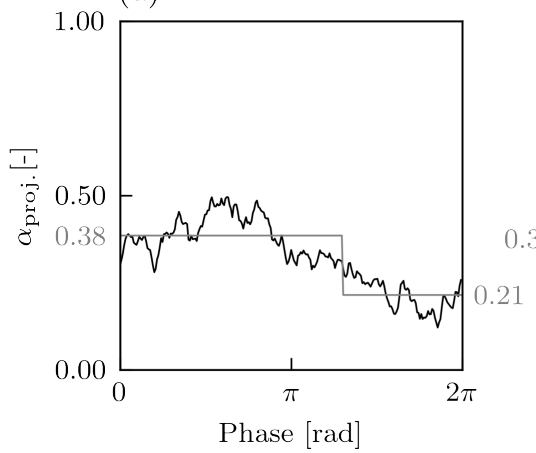

(b)

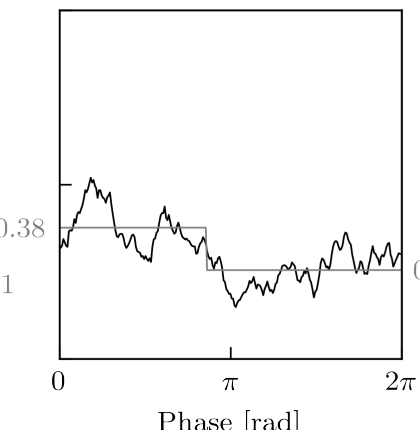

(c)

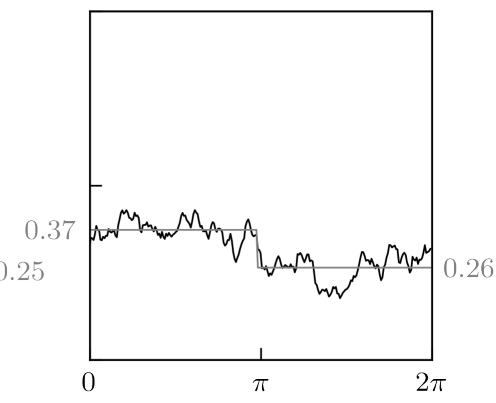

Phase [rad]

Fig. 8 Phase averaged wave (black line) and approximate rectangular wave (gray line) at (a) upstream, (b) midstream and (c) downstream measurement regions.

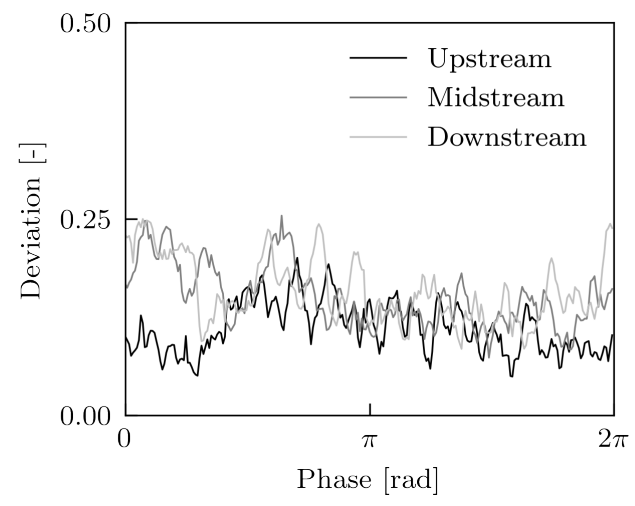

Fig. 9 Deviations defined by phase averaged waves at each measurement region.

これにより、1 周期分の気泡群の中で、比較的小 さい径の気泡は、気泡群全体が移流する間に前方 側から後方側へと移動する。気泡群内における気 泡の移動は、気泡群後方側のボイド率を増大させ る。近似矩形波の最小值の増大はこの結果現れた と考えられる。チャネルの上流と下流で気相の総 量は変化しないため、気泡群後方側のボイド率の 増大に応じて、ボイド率が減少した部分が存在す る。近似矩形波の最大值は上流から下流にかけて ほぼ変化しなかった。一方で、近似矩形波の最大 值が継続する長さが、上流においては半周期より 明らかに長いが、中流および下流においてはおよ そ半周期まで縮んだ。最大值が継続する長さが縮 小した分、気泡群後方側のボイド率が増大したこ とが分かる。また、近似矩形波の最大值はほぼ変 化せず最小值が増大した結果から、ボイド波は移
流中に最大值と最小值の差に当たる振幅を減衰 させることが確認された。

個々の気泡の速度差によって気泡群内で気泡 が前後に移動するとき、気泡群は下流へと移流す る間に流れ方向に伸張する。流れ方向の前後に位 置する別個の気泡群がそれぞれ伸張すると、前方 に位置する気泡群の末尾と後方に位置する気泡 群の先頭において、気泡群同士が合体を始めると 予想される。前後の気泡群の合体によるボイド波 の変動は、 $2 \mathrm{~Hz}$ の周期性に基づき計算された位相 平均波においては、位相ゼロおよび $2 \pi$ 付近に現 れる。Fig. 9 を見ると、上流においては、中流や 下流と比べてほぼ全ての位相で標準偏差が小さ い值を取る。上流における標準偏差を基準とする と、中流および下流において、位相ゼロおよび $2 \pi$ 付近に大きな標準偏差が現れた。気泡群の伸張は、 気泡径の違いから生じる、気泡ごとの速度差によ って引き起こされる。このため、気泡群の伸張度 合いは、気泡群内における気泡径分布に依存する。 個々の気泡群の内部に存在する気泡径の分布は、 注入時点から異なり、さらに移動中に発生する気 泡の結合や分離を経て変化し続ける。したがって、 気泡群の伸張の程度は気泡群ごとに異なる。この ため、気泡群同士の合体が生じると予想される位 相において、標準偏差が大きな值を示したと考え られる。

\section{2 ボイド波の移流拡散}

前節では、ボイド波の振幅が減衰した実験結果 の理由として、小さい径の気泡と大きい径の気泡 の速度差を考えてきた。個々の気泡が移動するこ 
とに対応するボイド率変動に注目すれば、気泡径 に応じた速度の差は波の分散性と解釈される。さ らに、ボイド波の変形を引き起こす現象として、 移流中の気泡の合体・分裂も想定される。これは、 波数空間でのエネルギー交換を意味する。これら のボイド波の変形を引き起こす現象は複合的に 作用し合うため、それを個々の気泡の動力学に遡 って記述することは困難である。本節は、このよ うな複合的作用の結果として実測された、ボイド 波全体の波形の情報を元に変形の評価を行う。ボ イド波の持続性に注目する立場から、実験によっ て確認されたボイド波の振幅の減衰を、時空間の 単位を有する単一の指標によって表す。この評価 に用いることができるボイド波の伝ぱ過程の定 式化が報告された前例は無く、ここでは簡便なモ デルとして空間 1 次元の移流拡散方程式

$$
\frac{\partial \alpha_{\text {proj. }}(t, x)}{\partial t}+U \frac{\partial \alpha_{\text {proj. }}(t, x)}{\partial x}=D \frac{\partial^{2} \alpha_{\text {proj. }}(t, x)}{\partial x^{2}}
$$

を用いることを考える。ここで、 $U$ と $D$ はそれぞ れボイド波の移流速度と拡散係数である。本実験 で計測されたボイド波 $\alpha_{\mathrm{proj}}$ が注入時に与えた周 波数 $f$ を移流後も維持していることに基づき、ボ イド波を周波数 $f$ で振動する波とみなす。式(4) の移流項 $U \partial \alpha_{\mathrm{proj}} / \partial x$ は波形に変化を与えないため、 気泡群の伸張によるボイド波の変形は拡散項 $D \partial^{2} \alpha_{\text {proj }} / \partial x^{2}$ により表現される。

\subsection{1 ボイド波の移流速度}

フーリエ変換を用いた解析により、ボイド波の 移流速度に相当する值として位相速度を求める。 ボイド率の時間変化にフーリエ変換を行うと、

Fig. 6 に示すボイド波の周波数成分ごとの強度に 加えて、周波数成分ごとの位相が得られる。可視 化画像の $x$ 方向それぞれの位置においてボイド波 を算出し、これにフーリエ変換を施すと、各位置 におけるボイド波の位相変化が読み取れる。気泡 群の移流後も維持された、注入周波数 $f=2 \mathrm{~Hz}$ の 成分に注目し、流れ方向の位相変化を Fig. 10 に 示す。位相が $x$ 方向に対して単調に減少している。 この傾きを、一次関数を仮定した最小二乗近似に よって計算することにより、ボイド波の主たる成 分の波数 $(k)$ が求められる。ボイド波の位相速 度は、

$$
U=\frac{2 \pi f}{k}
$$

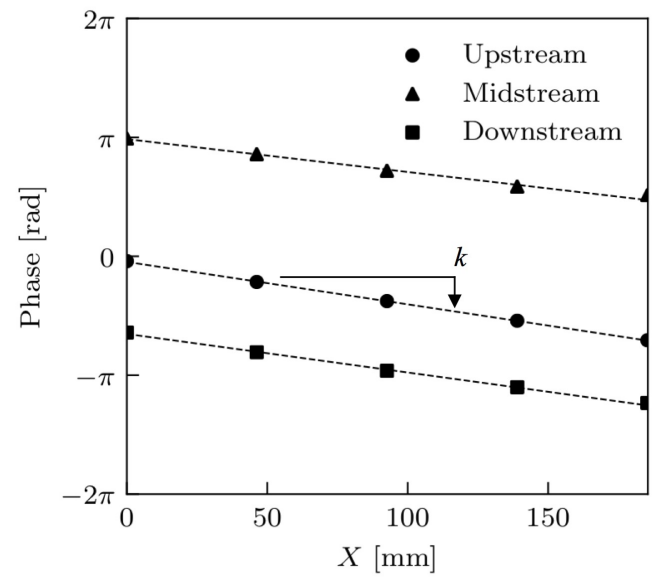

Fig. 10 Streamwise phase variation of void waves in each measurement region: plots are examples of measured phase, and dashed lines are linear approximations to the plots. The abscissa, $X$, represents streamwise distance from upstream end of each measurement region.

と定義される。

それぞれの計測点において算出された值は、上 流 $1.12 \mathrm{~m} / \mathrm{s}$ 、中流 $1.45 \mathrm{~m} / \mathrm{s}$ 、下流 $1.23 \mathrm{~m} / \mathrm{s}$ であっ た。これらの平均をとり、ボイド波の移流速度は $U=1.26 \mathrm{~m} / \mathrm{s}$ と求められ、チャネル乱流の平均流 速 $u_{\mathrm{m}}$ と同程度の值となった。過去の研究におい て、数 $\mathrm{mm}$ から数十 $\mathrm{mm}$ の径の気泡は水平チャネ ル乱流内で平均流速と同程度の速度で移動する ことが確認されており $[11,12,17]$ 、これに一致す る結果を得た。

\subsection{2 ボイド波の拡散係数}

式(4)の移流項はボイド波の変形を生じない。ボ イド波の変形を拡散係数で評価するにあたり、式 (4)を $\xi=x-U t$ によって変換して得られる、空間 1 次元の拡散方程式

$$
\frac{\partial \alpha_{\text {proj. }}(t, \xi)}{\partial t}=D \frac{\partial^{2} \alpha_{\text {proj. }}(t, \xi)}{\partial \xi^{2}}
$$

を用いる。本報では、上流側で計測された位相平 均波を初期条件として、任意の拡散係数を式(6) に与えて解き、計算により得られたボイド波形と 下流側で計測された位相平均波を比較すること で妥当な拡散係数を推定する。実験で得られた位 相平均波は、定点におけるボイド率の時間変化を 
表す。 1 周期分のボイド波が計測点を通過する間 の波形の変化が無視できるほど小さいと仮定し、 テイラーの凍結仮説を用いて、位相平均波を $\xi=x$ $-U t$ により変換する。この変換によって、元は 1 周期 $(0.5 \mathrm{~s})$ のボイド率変動を示した位相平均波 が、 1 波長 $(0.5 \mathrm{~s} \times U)$ の波形となる。

初期条件として使用寸るボイド波が離散的で あるため、式(6)をクランク・ニコルソン法[20]を 用いて離散化する。

$$
\frac{\alpha_{j}^{i+1}-\alpha_{j}^{i}}{\Delta t}=\frac{D}{2}\left(\frac{\alpha_{j+1}^{i+1}-2 \alpha_{j}^{i+1}+\alpha_{j-1}^{i+1}}{\Delta \xi^{2}}+\frac{\alpha_{j+1}^{i}-2 \alpha_{j}^{i}+\alpha_{j-1}^{i}}{\Delta \xi^{2}}\right)
$$

なお、 $\Delta t$ および $\Delta \xi$ は計算における時間と空間の 格子間隔であり、添え字 $i(0 \leq i \leq M)$ と $j(0 \leq j \leq$ $N+1)$ はそれぞれ時間ステップと空間ステップ の番号を表す。 $\Delta t$ は十分に細かい值として $1.0 \times 10^{-4} \mathrm{~s}$ に設定した。実験で得られた位相平均 波を $\xi$ の関数に変換して使用するため、 $\Delta \xi$ は高 速度カメラの撮影フレームレートに依存する。計 算においては、 $\Delta \xi$ は $U[\mathrm{~m} / \mathrm{s}] / 500[\mathrm{fps}]\left(\approx 2.5 \times 10^{-3}\right.$ m) となった。上流側の計測点におけるボイド率 の空間変動を $\alpha_{0}\left(\xi_{j}\right)$ と表すと、式(7)に与える初期 条件は

$$
\alpha_{j}^{0}=\alpha_{0}\left(\xi_{j}\right) \quad \text { for } 1 \leq j \leq N
$$

と記述される。ボイド波は周期性を持つため、 方向の境界には周期条件を与える。

$$
\left\{\begin{array}{l}
\alpha_{0}^{i}=\alpha_{N}^{i} \\
\alpha_{N+1}^{i}=\alpha_{1}^{i}
\end{array} \quad \text { for } 0 \leq i \leq M\right.
$$

なお、 $i=M$ のとき、ボイド波が下流側の計測点 に到達する。式(7)-(9)の下で、上流側の計測点か ら下流側の計測点へ移流する時間、ボイド波を時 間発展させる。移流に要した時間は、 $U=1.26 \mathrm{~m} / \mathrm{s}$ により、上流から中流で $1.59 \mathrm{~s}$ 、上流から下流で $3.25 \mathrm{~s} 、$ 中流から下流で $1.66 \mathrm{~s}$ と概算される。

式(7)における拡散係数 $D$ の值を変化させて、 拡散後のボイド率変動の波形 $\alpha_{j}^{M}$ を計算する。こ の数值解と、下流側で実際に計測されたボイド率 の空間変動 $\alpha_{\mathrm{f}}\left(\xi_{j}\right)$ について、

$$
\sum_{j=1}^{N}\left|\alpha_{\mathrm{f}}\left(\xi_{j}\right)-\alpha_{j}^{M}\right| \rightarrow \min .
$$

Table 2 Diffusion coefficients of void waves.

\begin{tabular}{cc}
\hline Measurement regions & $D\left[\mathrm{~m}^{2} / \mathrm{s}\right]$ \\
\hline Upstream to midstream & $1.88 \times 10^{-3}$ \\
Upstream to downstream & $1.54 \times 10^{-3}$ \\
Midstream to downstream & $1.17 \times 10^{-3}$ \\
\hline
\end{tabular}

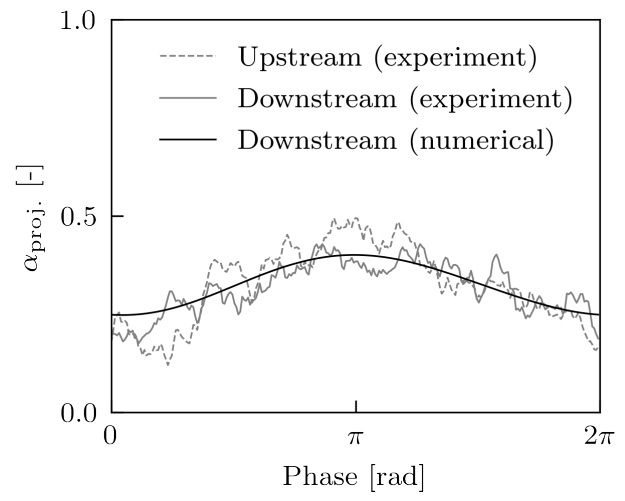

Fig. 11 Experimentally obtained phase averaged waves and a numerically matched void wave at $D=1.54 \times 10^{-3} \mathrm{~m}^{2} / \mathrm{s}$.

拡散係数の計算結果を Table 2 に示す。結果は 離散化の解像度や差分法の誤差の影響を含むが、 拡散係数を計算するための 2 つの計測点をいず れの組み合わせで選んだ場合でも、 $D \approx 10^{-3} \mathrm{~m}^{2} / \mathrm{s}$ で同じ桁の值となった。Fig. 11 に、上流および 下流で計測されたボイド波と、上流のボイド波に 算出された拡散係数を与えて予想される下流の ボイド波形について、それぞれの位相平均波を例 として示す。下流において、拡散方程式によって 予測される波形（Fig. 11 の黒実線）が計測され た波形（Fig. 11 の灰色の実線）によく合致して いる。

\section{2 .3 ボイド波の伝ぱ特性}

算出されたボイド波の移流速度と拡散係数か ら、式(4)の移流拡散方程式についてペクレ数を計 算する。計測点間の距離 $(L)$ を用いて、

$$
P e=\frac{U L}{D}
$$

とすると、 $P e>10^{3}$ である。これは、ボイド波が チャネル流路内を伝ぱする過程が、移流の作用に 支配されていることを示す。ボイド波を構成する 個々の気泡に注目するとき、気泡レイノルズ数は

となる $D$ をボイド波の拡散係数とする。 


$$
R e_{\mathrm{b}}=\frac{2\left|u_{\mathrm{m}}-U\right| r}{v}
$$

と定義される。可視化画像から気泡の半径 $r$ が 1 $\mathrm{mm}<r<100 \mathrm{~mm}$ 程度と確認されているため、径 が比較的小さい気泡においても $R e_{\mathrm{b}} \approx 300$ であり、 個々の気泡の運動において慣性力が支配的であ る。また、ボイド波 1 周期に相当する気泡群のレ イノルズ数を

$$
R e_{\mathrm{v}}=\frac{\left|u_{\mathrm{m}}-U\right| \lambda}{v}
$$

と定義する。ここでは、代表長さとして単一の気 泡群の波長 $\lambda(=U / f)$ を用いている。 $R e_{\mathrm{v}} \approx 1 \times 10^{5}$ となることから、気泡の集合体である気泡群につ いても、周囲の液相から受ける慣性力の作用が顕 著である。ボイド波の伝ぱにおいて移流の作用が 大きいことは、気泡群の運動が周囲流体から受け る慣性力により支配されることによると考えら れる。

式(11)で定義されるペクレ数は、ボイド波の伝 ぱにおける移流と拡散の作用を、チャネル流路全 体の規模で比較している。ここで、慣性力の作用 を気泡群のレイノルズ数と同様に評価して、気泡 群の波長程度の長さスケールでのペクレ数

$$
P e_{\mathrm{v}}=\frac{\left|u_{\mathrm{m}}-U\right| \lambda}{D}
$$

を定義する。 $P e_{\mathrm{v}} \approx 50$ であり、慣性の作用が大き いものの、拡散の影響が無視できない。3つの位 置で計測されたボイド波を比較したとき、周波数 は下流でも維持されたが、位相平均波の振幅は減 衰した。これは、ボイド波の波形を維持する慣性 の作用と、ボイド波の波形を変化させる拡散の作 用が同時に現れた結果と考えられる。また、チャ ネル流の局所壁面摩擦係数の経験式から[21]、本 実験の条件においては、乱流状態における值が同 じ流速の層流状態における值を外挿的に求めた 值より 100 倍ほど大きくなる。この局所壁面摩擦 係数の違いから生じる、乱流と層流の壁面摩擦の 差異を動粘性係数に代表させると、渦動粘性係数

$\left(v_{\mathrm{t}}\right)$ が水の動粘性係数のおよそ 100 倍と見積も られる。D物質拡散係数とみなした乱流シュミ ット数

$$
S c_{\mathrm{v}}=\frac{v_{\mathrm{t}}}{D}
$$

を計算すると、 $S c_{\mathrm{v}} \approx 0.05$ となる。これにより、 ボイド波の変形は、乱流中の速度変動の影響を受 けるものの、主にボイド分布の拡散によって現れ ていることが分かる。

$P e_{\mathrm{v}}$ および $S c_{\mathrm{v}}$ の值から、ボイド波の拡散の効 果は、慣性の効果と粘性の効果の中間程度の大き さであることが判明した。これは、慣性・拡散・ 粘性の作用の特性時間が、この順に大きくなるこ とを意味する。拡散係数が、径に依存した気泡の 速度差による気泡群の変形を代表するため、気泡 群の変形は次の(1)-(3)順の過程を辿ることが示 唆される。(1)慣性の効果によって、注入時の波形 が維持される、(2)拡散の効果が現れ、気泡の速度 差によって気泡群が伸張する、(3)粘性の影響によ り、液相の速度変動の影響を受けて気泡分布が変 動する。

\section{4. 結 言}

本研究では、水平チャネル乱流内に生成した人 工ボイド波の伝ぱの特性を調査した。チャネル乱 流内を移流する気泡群を、チャネルの上流、中流、 下流の 3 つの計測位置で高速度カメラを用いて 撮影し、撮影された画像からボイド率の時空間変 動を算出した。算出されたボイド波に対する解析 から、以下の知見を得た。

(1) 注入時に与えられたボイド波の周波数は、下 流においても維持される。ボイド波は移流す るにつれて変形し、振幅が減衰した。

(2) 1 次元移流拡散方程式をモデルとして、実験 で得られた波形からボイド波の振幅の減衰を 評価した。移流速度はチャネル平均流速と同 程度であり、拡散係数は $10^{-3} \mathrm{~m}^{2} / \mathrm{s}$ 程度となっ た。

(3) 拡散係数を用いた無次元数による比較から、 ボイド波の変形において、拡散の作用が乱流 内の粘性の作用より強く働くことが示された。 なお、船舶などで想定される片側平板乱流境界 層では、流れ方向に発達を続けることから、上記 の結果と異なる特性を持つ。これについては現在 調査中であり今後報告する予定である。 


\section{Nomenclature}

$H \quad$ : half height of channel [m]

$L \quad$ : distance between measurement regions [m]

$W \quad$ : width of channel [m]

$f \quad$ : injection frequency $\quad[\mathrm{Hz}]$

$Q_{\mathrm{g}} \quad$ : gas flow rate $\quad\left[\mathrm{m}^{3} / \mathrm{s}\right]$

$Q_{\mathrm{l}} \quad:$ liquid flow rate $\quad\left[\mathrm{m}^{3} / \mathrm{s}\right]$

$u_{\mathrm{m}} \quad:$ mean liquid velocity $\quad[\mathrm{m} / \mathrm{s}]$

$U \quad$ : advection velocity $\quad[\mathrm{m} / \mathrm{s}]$

$D \quad$ : diffusion coefficient $\quad\left[\mathrm{m}^{2} / \mathrm{s}\right]$

$k \quad:$ wavenumber $\quad\left[\mathrm{m}^{-1}\right]$

$\mathrm{Pe} \quad$ : Peclet number [-]

$P e_{\mathrm{v}} \quad$ : Peclet number of void waves [-]

Re : Reynolds number of channel flow [-]

$R e_{\mathrm{b}} \quad$ : Reynolds number of bubbles [-]

$R e_{\mathrm{v}} \quad$ : Reynolds number of void waves [-]

$S c_{\mathrm{v}} \quad$ : Schmidt number of void waves [-]

Greek letters

$\alpha_{\mathrm{m}} \quad$ : bulk void fraction

$\alpha_{\text {proj. }} \quad$ : projection void fraction

$v \quad:$ liquid kinematic viscosity

$v_{\mathrm{t}} \quad:$ turbulent eddy viscosity

\section{参考文献}

[1] McCormick, M. E. and Bhattacharyya, R., Drag Reduction of a Submersible Hull by Electrolysis, Nav. Eng. J., Vol. 85, 11-16 (1973).

[2] Kodama, Y., Hinatsu, M., Hori, T., Kawashima, H., Takeshi, H., Makino, M., Ohnawa, M., Sanada, Y., Murai, Y. and Ohta, S., A Full-Scale Air Lubrication Experiment Using a Large Cement Carrier for Energy Saving (Result and Analysis), Jpn. Soc. Nav. Archit. Ocean Eng., Vol. 6, 163-166 (2008).

[3] Kumagai, I., Takahashi, Y. and Murai, Y., A New Power-Saving Device for Air Bubble Generation Using a Hydrofoil for Reducing Ship Drag: Theory, Experiments, and Applications to Ships, Ocean Eng., Vol. 95, 183-194 (2015).

[4] Ceccio, S. L., Frictional Drag Reduction of External Flows with Bubble and Gas Injection, Annu. Rev. Fluid Mech., Vol. 42, 183-203 (2010).

[5] Murai, Y., Frictional Drag Reduction by Bubble Injection, Exp. Fluids, Vol. 55, 1-28 (2015).

[6] Fukuda, K., Tokunaga, J., Nobunaga, T., Nakatani, T. and Iwasaki, T., Frictional Drag Reduction with Air Lubricant over a Super-Water-Repellent Surface, J. Mar. Sci. Technol., Vol. 5, 123-130 (2000).

[7] Jang, J., Choi, S. H., Ahn, S., Kim, B. and Seo, J. S., Experimental Investigation of Frictional Resistance Reduction with Air Layer on the Hull
Bottom of a Ship, Int. J. Nav. Archit. Ocean Eng., Vol. 6, 363-379 (2014).

[8] Zhen, L. and Hassan, Y. A., Wavelet Autocorrelation of the Turbulent Flow Multi-Scales for Drag Reduction Process in Microbubbly Flows, Chem. Eng. Sci., Vol. 61, 7107-7114 (2006).

[9] Jacob, B., Olivieri, A., Miozzi, M., Campana, E. F. and Piva, R., Drag Reduction by Microbubbles in a Turbulent Boundary Layer, Phys. Fluids, Vol. 22, 115104 (2010).

[10] Hara, K., Suzuki, T. and Yamamoto, F., Image Analysis Applied to Study on Frictional-Drag Reduction by Electrolytic Microbubbles in a Turbulent Channel Flow, Exp. Fluids, Vol. 50, 715-727 (2011).

[11] Oishi, Y. and Murai, Y., Horizontal Turbulent Channel Flow Interacted by a Single Large Bubble, Exp. Therm. Fluid Sci., Vol. 55, 128-139 (2014).

[12] Murai, Y., Fukuda, H., Oishi, Y., Kodama, Y. and Yamamoto, F., Skin Friction Reduction by Large Air Bubbles in a Horizontal Channel Flow, Int. J. Multiph. Flow, Vol. 33, 147-163 (2007).

[13] Kitagawa, A., Denissenko, P. and Murai, Y., Behavior of Bubbles Moving along Horizontal Flat Plates with Different Surface Wettability, Exp. Therm. Fluid Sci., Vol. 104, 141-152 (2019).

[14] Oishi, Y., Murai, Y., Tasaka, Y. and Takeda, Y., Frictional Drag Reduction by Wavy Advection of Deformable Bubbles, J. Phys. Conf. Ser., 147, 012020 (2009).

[15] Park, H. J., Oishi, Y., Tasaka, Y. and Murai, Y., Void Waves Propagating in the Bubbly Two-Phase Turbulent Boundary Layer beneath a Flat-Bottom Model Ship during Drag Reduction, Exp. Fluids, Vol. 57, 1-18 (2016).

[16] Park, H. J., Tasaka, Y. and Murai, Y., Bubbly Drag Reduction Accompanied by Void Wave Generation inside Turbulent Boundary Layers, Exp. Fluids, Vol. 59, Article 166 (2018).

[17] Park, H. J., Tasaka, Y., Oishi, Y. and Murai, Y., Drag Reduction Promoted by Repetitive Bubble Injection in Turbulent Channel Flows, Int. J. Multiph. Flow, Vol. 75, 12-25 (2015).

[18] Park, H. J., Tasaka, Y., Murai, Y. and Oishi, Y., Vortical Structures Swept by a Bubble Swarm in Turbulent Boundary Layers, Chem. Eng. Sci., Vol. 116, 486-496 (2014).

[19] Takeuchi, T. and Kagawa, T., Applicability of Frequency Response Test for Stability Evaluation of Gas Pressure Regulator, Trans. Soc. Instrum. Control Eng., Vol. 49, 747-754 (2013).

[20] Crank, J. and Nicolson, P., A Practical Method for Numerical Evaluation of Solutions of Partial Differential Equations of the Heat-Conduction 
Type, Adv. Comput. Math., Vol. 6, 207-226 (1996).

[21] Dean, R. B., Reynolds Number Dependence of
Skin Friction and Other Bulk Flow Variables in Two-Dimensional Rectangular Duct Flow, Trans. ASME J. Fluids Eng., Vol. 100, 215-223 (1978). 